\title{
Kampanye Komunikasi Ecotransport dalam Mengurangi Transportasi Pribadi
}

\author{
Rahmadhani Ayu Harvianti", Oji Kurniadi \\ Prodi Ilmu Hubungan Masyarakat, Fakultas Ilmu Komunikasi Universitas \\ Islam Bandung, Indonesia \\ *daniaharvi10@gmail.com, oji.kurniadi@unisba.ac.id
}

\begin{abstract}
Ecotransport Indonesia is still fresh with diverse activities, from walking, public transportation, and cycling. The thing that is most crowded with the people of Bandung is cycling. Based on this phenomenon, the problem in this research is formulated as follows: (1) How does ecotransport plan a communication campaign program about reducing personal transportation? (2) How does ecotransport choose media as a publication tool? (3) Why does ecotransport use a persuasive approach in the communication campaign to reduce personal transportation? Researcher using qualitative case studies. Data collection techniques used in this study were interviews with key informan, observation, and literature. The results of this study are: The results obtained from this research are (1) the planning of the campaign carried out by determining the issues raised, one of which is in the discipline of driving, setting goals to provide education about environmentally friendly transportation or by other names Ecotransport, determining the message delivered to the public, this audience from Ecotransport which is not only focused on the community but also on the government as well and the strategy used is communication that is done face-to-face and persuasive through social media but still not maximized. (2) Media publications include conducting talk shows on the radio, in addition to making e-posters uploaded through social media. (3) The use of face-to-face communication to provide clear explanations will protect the environment.
\end{abstract}

\section{Keywords: Communication, Campaign, Eco, Transport.}

Abstrak. Ecotransport Indonesia ini terbilang masih fresh dengan kegiatan yang beraneka ragam, dari berjalan kaki, transportasi umum dan bersepeda. Hal yang paling ramai diikuti oleh masyarakat kota Bandung adalah bersepeda. Berdasarkan fenomena ini, masalah dalam penelitian ini dirumuskan sebagai berikut: (1) Bagaimana ecotransport merencanakan program kampanye komunikasi tentang pengurangan transportasi pribadi? (2) Bagaimana ecotransport memilih media sebagai alat publikasi? (3) Mengapa ecotransport menggunakan pendekatan persuasif dalam kampanye komunikasi untuk mengurangi transportasi pribadi? Peneliti menggunakan studi kasus kualitatif. Teknik pengumpulan data yang digunakan dalam penelitian ini adalah wawancara dengan informan kunci, observasi, dan studi pustaka. Hasil yang diperoleh dari penelitian ini adalah (1) perencanaan kampanye yang dilakukan adalah menentukan isu yang diangkat salah satunya adalah dalam disiplin berkendara, penyusunan tujuan untuk memberikan edukasi mengenai transportasi ramah lingkungan atau dengan nama lain Ecotransport, menentukan pesan yang disampaikan kepada khalayak publik, khalayak dari Ecotransport ini yang tidak hanya terfokus kepada masyarakat saja melainkan kepada pemerintah juga dan strategi yang digunakan adalah komunikasi yang dilakukan secara face-to-face dan persuasive melalui media sosial dan hasilnya belum maksimal. (2) Media publikasi yang dilakukan yaitu melakukan talkshow di radio, selain itu dengan membuat e-poster yang diunggah melalui media sosial. (3) Penggunaan komunikasi secara tatap muka ini untuk memberikan penjelasan yang jelas akan menjaga lingkungan sekitar.

Kata Kunci: Komunikasi, Kampanye, Ramah lingkungan, kendaraan. 


\section{A. Pendahuluan}

Banyaknya penduduk memungkinkan bahwa masyarakat mempunyai kendaraan pribadi tidak hanya satu melainkan dua atau lebih. Dengan alasan bahwa kendaraan umum sudah tidak lagi aman dan jika menunggu angkutan sedang berhenti terlalu lama dapat membuat kita sebagai penumpang merasakan panik karena tidak ingin terlambat ke tempat tujuan. Sebaliknya, jika mempunyai kendaraan pribadi dapat mempermudah dan mempercepat berpergian kemanapun tujuan dengan waktu yang kita inginkan. Badan statistik menyebutkan pada tahun 2013 jumlah kendaraan roda empat pribadi di Kota Bandung sebanyak 318.598 dan motor sebanyak 1.030.729. Setiap tahunnya angka tersebut akan meningkat dan membuat jalanan penuh dengan kendaraan terutama kendaraan pribadi.

Neiburger et.al (1995) menyatakan pula bahwa pembakaran bahan bakar untuk menghasilkan energi adalah sumber utama pencemaran udara. Unsur-unsur ini bila mencapai kuantum tertentu dapat merupakan racun bagi manusia atau hewan serta mengganggu kesehatan manusia. Sebagai contoh gas $\mathrm{CO}$ merupakan racun agi fungsi-fungsi darah, sedangkan $\mathrm{CO}_{2}$ dapat menimbulkan penyakit system pernapasan. (Sembel, 2015:43). Hal ini dapat membuat pengendara mengalami stress, emosi, menghirup polusi karena disebabkan oleh banyak kendaraan yang ada dijalan.

Kemudian pemerintah Kota Bandung mengalami kerugian sebesar 4,36 triliun/tahun akibat kemacetan dan polusi. Perlu adanya solusi mengatasi kemacetan dan meminimalisir agar penggunanaan kendaraan pribadi agar berkurang. Hal yang perlu dilakukan adalah menggunakan sepeda, angkutan umum dan berjalan kaki. Ecotransport ini adalah ide dari beberapa tokoh dari komunitas Kota Bandung yang dulunya dengan nama Bandung Ecotransport dan sekarang berubah menjadi Ecotranport Indonesia. Ecotransport ini mengajak para pengguna kendaraan pribadi untuk beralih menggunakan kendaraan umum dan alangkah lebih baiknya lagi jika menggunakan sepeda. Maka dari itu program dari ecotransport yang diikuti masyarakat mereka sudah menjadi salah satu relawan yang dapat membuat dilingkungan sekitar akan terpengaruh.

Kota Bandung memprogamkan kota yang ramah lingkungan, indah, bersih dan sehat, serta berusaha terus-menerus untuk memperbaiki sarana publik agar dapat dinikmati oleh warga Bandung dan juga luar Bandung. Dari hal ini Ecotransport ingin mengajak semua orang untuk tersadar akan kebersihan, kenyamanan dan keamanan publik untuk saling menjaga sarana publik dan menggunakan sarana publik sesuai dengan sebagaimana mestinya. Kalau bukan dari kita siapa lagi yang akan melakukan hal tersebut.

Berdasarkan latar belakang yang telah diuraikan, maka perumusan masalah dalam penelitian ini sebagai berikut: "Kampanye Komunikasi Eco Transport dalam Mengurangi Penggunaan Transportasi Pribadi". Selanjutnya, tujuan dalam penelitian ini diuraikan dalam pokok-pokok sbb.

1. Untuk mengetahui cara Ecotransport merencanakan program kampanye komunikasi mengenai pengurangan transportasi pribadi.

2. Untuk mengetahui media yang digunakan Ecotransport sebagai alat untuk memberikan informasi.

3. Untuk mengetahui pendekatan persuasif yang digunakan Ecotranport dalam kampanye mengenai pengurangan transportasi pribadi.

\section{B. Landasan Teori}

Suatu kegiatan kampanye berawal dari komunikasi. Everett M.Rogers dalam buku Cangara (2012:22) mendefinisikan komunikasi adalah proses di mana suatu ide dialihkan dari sumber kepada satu penerima atau lebih, dengan maksud untuk mengubah tingkah laku mereka. Mereka disini adalah publik yang akan menerima pesan dari komunikator. Pesan komunikasi yang disampaikan pada saat ini bisa dilakukan dengan berbagai macam cara. Dari cara yang dilakukan oleh seorang komunikator untuk menyampaikan pesan akan mendapatkan efek yang telah dipahami. Efek yang didapatkan bisa jadi perubahan perilaku, opini, pandangan dan kepercayaan. 
Jika disambungkan dengna kampanye, tentulah ada beberapa strategi komunikasi didalamnya. Menurut Ruslan (2005) dalam buku Kampanye Public Relations, strategi itu pada hakikatnya adalah suatu perencanaan (planning) dan manajemen (management) untuk mencapai tujuan tertentu dalam praktik operasionalnya. Komunikasi secara efektif adalah sebagai berikut.

1. Bagaimana mengubah sikap (how to change the attitude)

2. Mengubah opini (to change the opinion)

3. Mengubah perilaku (to change behaviour)

Menurut R. Wayne Pace, Brent D. Peterson dan M. Dallas Burnett mengenai tujuan strategi komunikasi adalah sebagai berikut.

1. To secure understanding

Untuk memastikan bahwa terjadi suatu pengertian dalam berkomunikasi

2. To establish accepptance

Bagaimana cara penerimaan itu terus dibina dengan baik

3. To motive action

Penggiatan untuk memotivasinya

4. The goals which the communicator sought to achieve

Bagaimana mencapai tujuan yang hendak dicapai oleh pihak komunikator dari proses komunikasi tersebut (Ruslan, 2005:37)

Penelitian ini menggunakan teori persuasi intregasi informasi dan perubahan sikap yang dikemukakan oleh Heath (2005), dimana teori ini begitu sederhana, yaitu menjelaskan bahwa individu membentuk sikapnya dengan cara memadukan atau mengintegrasikan informasi atau hal-hal yang positif maupun negatif. Kemudian kampanye pada hakikatnya adalah tindakan komunikasi yang bersifat goal oriented. Pada kampanye selalu ada pencapaian tujuan tertentu. Pencapaian tujuan tersebut tidak bisa langsung dalam bertindak melainkan harus didasari tindakan secara sistematis dan dibutuhkan juga sebuah strategi. Aktivitas proses komunikasi kampanye untuk mempengaruhi khalayak dengan membujuk dan memotivasi utnuk berpartisipatif, ingin menciptakan efek atau dampak tertentu sesuai yang direncanakan, dilaksanakan dengan tema spesifik dan narasumber yang jelas.

Menurut Ostegaard (2002) menyebutkan tiga aspek upaya perubahan yang dilakukan kampanye dengan istilah ' $3 \mathrm{~A}$ ' sebagai singkatan dari awareness, attitude, dan action. Dalam buku Venus (2004:10) ketiga aspek itu dijabarkan sebagai berikut. Pada tahap pertama kegiatan kampanye biasanya diarahkan untuk menciptakan perubahan pada pengetahuan atau kognitif dan pengaruh yang diharapkan dalam tahap ini adalah memunculkan kesadaran, berubahnya keyakinan atau meningkatnya pengetahuan khalayak mengenai isi dalam kampanye. Tahap kedua diarahkan pada perubahan dalam ranah sikap atau attitude yang sasarannya aladah untuk memunculkan simpati, rasa suka, kepedulian atau berkepihakan khalayak pada isu-isu dalam tema kampanye. Dan tahap terakhir kegiatan kampanye ditujukan untuk mengubah perilaku khalayak secara konkret dan terukur dimana tahap ini menghendaki adanya tindakan tertentu yang dilakukan oleh sasaran kampanye dimana tindakan tersebut dapat bersifat sekali itu saja atau berkelanjutan (terus menerus).

Fungsi dan tugas dari seorang Public Relations (PR) adalah menyebarluaskan informasi melalui berbagai media tentang kegiatan organisasi, yang harus diketahui oleh publik. PR juga bertugas untuk menghasilkan publisitas untuk mendapatkan tanggapan yang positif dari publik. Publisitas dapat dilakukan melalui events, campaigns, dan program. (Ardianto, 2013:261)

Menurut Ardianto (2013:262), mendefinisikan publisitas sebagai berikut:

1. Suatu teknik bercerita mengenai seseorang, suatu badan, suatu hal.

2. Teknik untuk mengerahkan perhatian dan kemauan baik dari publik terhadap seseoran atau suatu badan.

3. Berita mengenai kejadian-kejadian yang direncanakan.

4. Teknik penyiaran suatu berita mengenai peristiwa yang direncanakan terlebih dahulu dalam media massa tanpa membayar untuk kepentingan seseorang, suatu badan atau suatu hal.

5. Publicity is planned news.

6. Publicity is good news, not bad news. 
Peneliti ingin mengetahui media yang digunakan oleh Eco Transport dalam menyebarluaskan informasi. Suatu organisasi tentu memperkenalkan kegiatan dari kampanye agar masyarakat mau mendukung serta informasi yang didapat kedepannya dapat disebarluaskan kembali ke masyarakat yang lainnya seperti teman, keluarga, dan lainnya.

Terdapat beberapa definisi publisitas yang terdapat dalam buku PR Writing (Kriyantono, 2012:41), sebagai berikut:

1. Segala informasi atau tindakan yang membawa seorang individu menjadi dikenal publik (any information or action that brings a person to public notice).

2. Segala kegiatan yang dilakukan untuk mengenalkan perusahaan dan/atau produk kepada masyarakat melalui media massa (any activities of introducing the company and or its products to large number of people through mass media).

3. Otis Baskin, dkk mendefinisikan publisitas sebagai istilah yang merujuk pada publikasi berita tentang organisasi atau individu di mana untuk itu tidak perlu membayar waktu atau space (a broad term that refers to the publication of news about an organization or person for which time or space was not purchased).

Dari definisi diatas, penulis dapat menyimpulkan bahwa melalui publisitas informasi seseorang akan diketahui oleh publik. Kegiatan yang dilakukan perusahaan akan produknya diperkenalkan melalui media massa tanpa memerlukan biaya.

Pemasaran sosial merupakan strategi pada aktivitas non komersial yang bertujuan untuk memecahkan berbagai masalah sosial yang terjadi di masyarakat. Konsep yang digunakan adalah Teknik pemasaran dan komunikasi sehingga dalam pelaksanaannya akan sangat memertimbangkan product, price, place, dan promotion serta menggunakan Teknik komunikasi yang tepat (Pudjiastuti, 2016: 6)

Pemasaran sosial sering juga disebut dengan kampanye sosial, karena dalam pelaksanaannya menggunakan strategi kampanye. Hal yang dikampanyekan adalah cara-cara atau produk sosial untuk mengatasi masalah sosial yang ada di masyarakat.

\section{Hasil Penelitian dan Pembahasan}

\section{Perencanaan Kampanye Komunikasi yang dilakukan Ecotransport}

Proses perencanaan kampanye komunikasi diawali dengan kegiatan ngobrol-ngobrol perlunya edukasi bagi pesepeda dijalan raya tentang keselamatan pesepeda dan perilaku pesepeda ketika mengendarai sepeda. Program kampanye ini nantinya menjadik spirit yang bisa diikuti oleh semua orang. Dalam menentukan sasaran, Ecotransport menargetkan pemerintah dan untuk sasaran program-program kegiatannya adalah seluruh masyarakat.

Proses pengelolaan kampanye sepeda ini, Ecotransport membuat kegiatan konsisten sebagai wahana bertemu. Kemudian ecotransport membuat goals bersama dalam waktu terukur. Seperti halnya kata "Indonesia Bersepeda" itu muncul dari kota Bandung. Rencana selanjutnya dalam seminggu minimal dua kali, tidak di hari libur, bertema dan masukan ajakan-ajakan positif sejak awal. Ecotransport tidak hanya merencanakan untuk melakukan kampanye secara langsung saja melainkan menggunakan media sosial. Unggahan di media sosial tersebut berisikan tentang selalu mengingatkan dengan kata-kata yang kekinian seperti ajak teman biar gak kesepian, kenakan helm biar ganteng, bawa tumblr biar gak nyampah dan lainnya. Kampanye ini meggunakan e-poster, yang sudah mengikuti kegiatan kampanye ini bisa meminta untuk menggunakan fotonya ketika akan diunggah melalui media sosial.

Program kampanye ini dibuat secara menarik dikarenakan seluruh masyarakat dapat mengikuti kampanye ini karena berhubungan tidak hanya terfokuskan kepada transportasi ramah lingkungan saja tetapi cara kita menjaga kelestarian lingkungan dan cara bersikap. Pesanpesan dari kampanye sepeda ini dirancang dengan bahasa yang dimengerti semua masyarakat. Menurut penulis isi pesan yang disampaikan Ecotransport ini menarik dan dapat dimengerti oleh masyarakat. Karena pesan yang disampaikan tidak keras dan memaksa untuk mengikutinya. Kalau dengan memaksa hasilnya tidak akan baik, maka dari itu kampanye sepeda ini dibuat santai, menarik dan menyenangkan agar memberikan efek positif. 


\section{Pemilihan Media Sebagai Alat Publikasi}

Klingemann dan Rommele (Venus,2018:141) secara spesifik mengartikan saluran kampanye sebagai bentuk medium yang digunakan untuk menyampaikan pesan kepada khalayak. Ecotransport Indonesia menggunakan media sosial dan media elektronik sebagai alat publikasi kampanye sepeda ini. Sungguh sangat tepat sekali ecotransport dalam pemilihan media ini, karena masyarakat dari berbagai kalangan ada yang sudah menggunakan media sosial dan juga masih ada yang menggunakan media elektronik. Media yang paling tepat digunakan oleh ecotransport dalam menyampaikan pesan yaitu radio, whatsapp, facebook, Instagram dan twitter. Media penyampai pesan ini dipadukan dengan konten-konten menarik sesuai dengan tema yang bersangkutan.

Dilihat dari saluran penyampaian pesan kampanye, ecotransport menggunakan saluran tatap muka. Saluran ini dimana memungkinkan untuk munculnya interaksi, motivas hingga penguatan secara langsung dari penyampaian pesan atau penyelenggara kampanye kepada publik, baik yang baru menyadari suatu gagasan maupun yang sudah mencoba gagasan tersebut. Pada era digital seperti sekarang ini, membuat ruang publik dibanjiri oleh berbagai informasi. Dalam hal ini, penggunaan media yang telah dipilih oleh ecotransport terbukti efektif. Karena dengan penggunaan gambar dan video yang diunggah oleh ecotransport dapat membuat publik tertarik dalam informasi pesan yang telah disampaikan.

Berkaitan dengan sebelumnya bahwa pemilihan media yang dilakukan oleh ecotransport ini adalah untuk menyebarkan informasi dan memotivasi khalayak sasaran kampanye. Hal yang paling penting dari saluran media ini adalah komunikator yang menyampaikan dan menyebarkan pesan karena dari semua kalangan umur memunculkan pesan yang disampaikan akan berbeda agar tetap kepada tujuan yang sama.

\section{Kampanye Ecotransport Dengan Pendekatan Sosial}

Dari teori-teori persuasi dapat membantu mengidentifikasi proses-proses yang terjadi ketika pesan-pesan kampanye diarahkan untuk memengaruhi sikap dan perilaku khalayak. Seorang komunikator komunikasi memiliki peranan yang dimana siapapin yang terlibat dalam meggagas, merangcang, memanajemen dan menyampaikan dalam sebuah kegiatan kampanye dapat dikatakan pelaku kampanye.

Seperti halnya pada ecotransport Indonesia ini, penulis menginterpertasikan hasil pernyataan dari kedua informan mengenai siapa saja yang dapat dijadikan komunikator dalam kampanye ini dan hasilnya adalah siapapun yang tertarik, bergabung dan mendukung kegiatan kampanye ini dapat dikatakan sebagai relawan dari ecotransport dengan arti dapat menyebarkan dengan luas informasi mengenai kampanye sepeda ini. Dalam kampanye membutuhkan komunikator lain yang mampu memberikan efek lebih kepada kampanye ini. Karena kegiatan sepeda ini sudah banyak dari komunitas sepeda di Kota Bandung yang membantu untuk mengkampanyekan kegiatan bersepeda tetapi masih ada yang belum tergugah untuk keinginan berubah.

Persuasi didefinisikan sebagai "perubahan sikap akibat paparan informasi dari orang lain". Sikap pada dasarnya adalah tendensi kita terhadap sesuatu. Sikap adalah rasa suka/tidak suka kita atas sesuatu. Konsep lain yang terkait erat dengan sikap adalah kepercayaan, atau pernyataan-pernyataan yang dianggap benar oleh seseorang. (Werner \& James, 2014: 177)

Tindakan dari persuasif dalam kampanye berbeda dengan tindakan persuasif perorangan. Aspek-aspek yang ada dalam kegiatan kampanye persuasif ini merupakan kampanye secara sistematis yang berupaya menciptakan pemikiran khalayak mengenai gagasan yang diberikan, kemudian kampanye berlangsung dari cara menarik perhatian khalayak, menyiapkan khalayak untuk bertindak, hingga pada akhirnya mampu mengajak khalayak lain untuk melakukan tindakan nyata. Kampanye juga membuat gagasan-gagasan yang akan disampaikan kepada khalayak dan mengundang mereka untuk terlibat didalam kampanye untuk mencapai tujuan kampanye. Kampanye juga menggunakan media massa dalam upaya menyadarkan hingga mengubah perilaku masyarakat. 


\section{Kesimpulan}

Berdasarkan pembahasan dalam penelitian ini, peneliti menyimpulkan beberapa hasil penelitian sebagai berikut:

1. Perencanaan kampanye yang dilakukan Ecotransport adalah kesadaran akan memahami situasi sekeliling dengan strategi membuat kegiatan semenarik mungkin kemudian pelan-pelan diajak membangun rekayasa sosial positif bahwa bersepeda tidak sesederhana mengayuh saja, lebih banyak melakukan inovasi untuk terus menggerakkan masyarakat agar berkenan memahami bahwa yang dimiliki secara pribadi itu kendaraannya bukan jalannya Mempunyai tujuan yaitu perilaku bijak pada orang-orang yang berkenan sadar pada bumi lestari, gak macet dan bijak menggunakan kendaraan pribadi. Hasilnya belum maksimal

2. Media sosial yang digunakan sebagai alat publikasi yaitu Instagram dan twitter. Ecotransport telah bekerja sama dengan radio RRI dan KLCBS pada timing dengan tema komunitas. Untuk berbagi informasi yang detail bai kantar komunitas maupun nonkomunitas menggunakan whatsapp.

3. Alasan ecotransport menggunakan komunikasi persuasif melalui personal touch dan eposter adalah untuk masyarakat medapatkan informasi dimulai dari saat ini dan nanti, kemudian bagaimana keyakinan masyarakat akan informasi yang telah didapat dan mengajak masyarakat untuk turun langsung ke lapangan.

\section{E. Saran}

\section{Saran Teoritis}

1. Penulis berharap untuk penelitian selanjutnya yang tertarik melakukan penelitian mengenai ecotransport agar lebih dilengkapi dan disempurnakan dilihat dari sudut pandang yang berbeda dari bidang Ilmu Komunikasi khususnya Public Relations.

2. Penulis menyarankan agar buku-buku mengenai kampanye public relations, komunikasi persuasif dan studi kasus lebih diperbanyak.

3. Untuk penelitian kedepannya, diharapkan menggunakan pendekatan kuantitatif, lebih condong ke komunitas dan menggunakan teori kampanye PR, sehingga pada penelitian selanjutnya dapat membuktikan kebenaran dari teori yang digunakan.

\section{Saran Praktis}

1. Penulis menyarankan agar kampanye ecotransport bisa meluas lagi dengan menggunakan media sosial yang lainnya seperti facebook, line, youtube.

2. Karena ecotransport ini sudah berganti nama yang awalnya cuma di Bandung saja dan sekarang menuju seluruh Indonesia sebaiknya dibuat organisasi besar dengan mempunyai visi dan misi yang jelas. Karena banyak anak muda yang berkeinginan ikut organisasi yang bersifat positif.

3. Alangkah lebih baiknya lagi selain bekerja sama di sekolah-sekolah saja, jalinan kerjasama dengan mahasiswa dan karyawan lebih ditingkatkan lagi untuk membiasakan pergi dari rumah menggunakan sepeda.

\section{Daftar Pustaka}

Ardianto, Elvinaro. 2013. Handbook of Public Relations. Bandung: Simbiosa Rekatama Media. Cangara, Hafied. 2012. Pengantar Ilmu Komunikasi. Jakarta: PT. Rajagrafindo Persada.

Kurniasih, Dian. 2017. Strategi Kampanye Komunikasi Publik WWFIndonesia dalam Kampanye \#Berliyangbaik untuk Meningkatkan Kesadaran terhadap Produk Ramah Lingkungan. Sarjana Thesis, Universitas Brawijaya.

Pudjiastuti, Wahyuni. 2016. Social Marketing: Strategi Jitu Mengatasi Masalah Sosial di Indonesia. Jakarta: Yayasan Pustaka Obor Indonesia.

Ruslan, Rosady. 2014. Manajemen Public Relations dan Media Komunikasi Konsepsi 
Severin, Werner J., James W. Tankard, Jr. 2014. Teori Komunikasi: Sejarah, Metode, dan Terpaan di Dalam Media Massa Edisi Kelima. Jakarta: Kencana

Venus, Antar. 2004. Manajemen Kampanye Panduan Teoritis dan Praktis dalam Mengefektifkan Kampanye Komunikasi. Bandung: Simbiosa Rekatama Media. 